\title{
Opinions on the economic impact of the COVID -19 crisis and the world after - an international perspective
}

\author{
Adrian Tudor TUDORACHE \\ Bucharest University of Economic Studies, Bucharest, Romania \\ tudortudorache@yahoo.com \\ Luminița NICOLESCU \\ Bucharest University of Economic Studies, Bucharest, Romania \\ luminicolescu@yahoo.com
}

\begin{abstract}
The COVID crisis affected the whole world at an unprecedented and unexpected level. There are concerns about the economic impact of the crisis and about how the world will be after the COVID-crisis ends. The present paper had as main objective to analyze the opinions of specialists about two aspects: a) economic impact of the COVID crisis at different levels in the economy (world, national economy, industry, business) and b) how will be the world order in the aftermath of the COVID crisis. The methodology used is literature review and documentation, followed by content analysis. The research revealed that the impact of the COVID-19 outbreak was huge at all levels in the economy, resulting in a global recession. Also, specialists appreciate that the world will not go back to how it was in 2019, there will be a clear distinction between the pre-COVID and the post-COVID eras, with a need for a new economic order after the crisis, that will emphasize global solidarity for the purpose of the common good.
\end{abstract}

Keywords: COVID crisis, economic impact, new world order.

\section{Introduction}

The COVID crisis affected the whole world at an unprecedented and unexpected level. There are concerns about the economic impact of the crisis and about how the world will be after the COVID-crisis ends (Bremmer, 2020; Manyika, 2020). As a very actual topic that also has paramount importance for the future, this is highly debated in the literature. There are papers that focus on the impact of the crisis at a general level (Ibn-Mohammed et al., 2021), there are also others that focus on the impact of COVID outbreak on particular industries, such as airlines (Amankwah-Amoah et al., 2021) or auto industry (Belhadi et al., 2021) and there are papers that look at the future and how the world will look like when it will be normalized after the COVID crisis would have passed (Buscher et al., 2021; Rebelo, 2020; Sneader \& Singhal, 2021).

The present paper had as main objective to analyze and synthesize the opinions of specialists about these two aspects: a) economic impact of the COVID crisis at different levels in the economy (world, national economy, industry, business) and b) how will be the world order in the aftermath of the COVID crisis. In order to reach this objective, the paper is organized as follows: the next section contains data and facts about the COVID health crisis evolution, as well as the main actions taken by governments worldwide; this is followed by the methodology section; the fourth section classifies the economic impact of the crisis in more categories and discusses it at more levels, based on the findings from the literature and the data from international statistics; the fifth section looks at what specialists feel about what will come after the COVID crisis will end; the paper ends with the conclusion. 


\section{The health crisis: facts and actions COVID-19 crisis: facts}

The first case of pneumonia determined by an unknown cause was announced to the World Health Organization (WHO) in December 2019 originating from the Wuhan province, China. Very fast doctors realized that the cause was a new type of Coronavirus, called with its official name Severe Acute Respiratory Syndrome Coronavirus 2 (SARS-CoV 2) and the disease it provokes was called COVID-19 (WHO, 2020).

The virus and the disease started to spread from one country to another. The strong interconnectedness that exists between countries facilitated the expansion of the virus and the disease (Gruszczynski, 2020, p. 337) at a global level. On 11 March 2020, the WHO declared a global pandemic of COVID-19 (WHO Timeline, 2021). The disease spread and registered an increasing evolution for the whole year 2020. COVID-19 provoked many losses of human lives and health systems all over the world were under strain and did not cope with the avalanche of ill people who needed intensive care.

Table 1 presents the evolution of COVID-19 cases and deaths at the world level in the period January 2020-February 2021, using daily data presented at the beginning of each month of the year, up to 15 February 2021.

Table 1. Number of cases and deaths related to COVID-19 at world level

\begin{tabular}{|l|c|c|c|}
\hline Month and year & Number of active cases* & Death rate (\%) & Number of daily new cases \\
\hline 22 January 2020 & 977 & - & - \\
\hline 1 February 2020 & 14.397 & $40,19 \%$ & - \\
\hline 2 March 2020 & 42.835 & $6,33 \%$ & $\begin{array}{c}19.376 \\
\left(15^{\text {th }} \text { of March 2020) }\right.\end{array}$ \\
\hline 2 April 2020 & & & 81.459 \\
\hline 2 May 2020 & 792.240 & $20,41 \%$ & 96.316 \\
\hline 1 June 2020 & 2.039 .017 & $15,44 \%$ & 123.077 \\
\hline 1 July 2020 & 2.914 .961 & $10,52 \%$ & 213.488 \\
\hline 1 August 2020 & 4.077 .887 & $7,25 \%$ & 277.114 \\
\hline 2 September 2020 & 5.759 .987 & $5,47 \%$ & 292.099 \\
\hline 2 October 2020 & 6.680 .864 & $4,41 \%$ & 328.479 \\
\hline 1 November 2020 & 7.436 .288 & $3,70 \%$ & 471.969 \\
\hline 2 December 2020 & 11.205 .668 & $3,31 \%$ & 645.356 \\
\hline 2 January 2021 & 16.899 .738 & $3,08 \%$ & 575.229 \\
\hline 2 February 2021 & 20.475 .722 & $2,87 \%$ & 456.201 \\
\hline 15 February 2021 & 23.836 .938 & $2,82 \%$ & 303.696 \\
\hline
\end{tabular}

* Active Cases = (total cases) - (total deaths) - (recovered), representing the current (in that respective day) number of people detected and confirmed to be infected with the virus.

Source: https://www.worldometers.info/coronavirus/.

The total number of COVID cases increased over the whole year of 2020, as the number of new daily cases also registered an increasing trend during 2020. Death rates, however, decreased over 2020. Only at the beginning of 2021, the number of new daily cases and the number of active cases started to decrease, probably in conjunction with the vaccination campaigns. On 16 February 2021, the total number of cases registered at the world level since the beginning of the pandemic was 109.690 .062 with a total number of deaths of $2.419 .172^{1}$.

\footnotetext{
${ }^{1}$ https://www.worldometers.info/coronavirus/.
} 


\section{COVID-19 crisis: actions}

After the COVID-19 outbreak, all countries took measures and tried to contain the virus, and the disease spread. The health-related measures included:

- local, regional, and national lockdowns with schools, shops, restaurants being closed;

- country borders were closed and travel restrictions have been imposed;

- social distancing rules and stronger sanitization were also put in place;

- increased supply of intensive care medical equipment (albeit global shortages of ventilators, masks in the first months of the outbreak).

In some countries, medical measures were supplemented by emergency financial packages.

The economic-related measures included: credit offering to businesses and income support for people who lost their jobs (Leach et al., 2021), credit payments delays for companies and the population. In the EU in April 2020, there were approved half-trillion Euros for the members states in order to both fight the pandemic and also overcome the economic impact of the health crisis (Sharfuddin, 2020).

Medical and pharmaceutical companies started to intensively work for the development of vaccines for the COVID-19 in order to stop the pandemic. The coronavirus pandemic is expected to end when herd immunity is achieved: "herd immunity to a pathogen is achieved when a sufficient portion of the population is simultaneously immune to prevent sustained transmission" (Charumilind et al., 2021, p. 2) and the necessary portion of the population is considered to be $70 \%$ of the population. Immunization can occur by either people making the disease and getting antibodies or by forming these antibodies via vaccine immunization.

A number of vaccines have been already developed and started to be used in different countries of the world (Pfizer-BioNTech - multinational origin, Moderna from the US, AstraZeneca from the UK, Sputnik from Russia, CoronaVac from China) and some others are under development (Johnson\&Johnson, Novavax, CureVac, Sanofi-GSK, etc.) and in clinical trials ${ }^{2}$. Vaccination started on 13 December 2020 and on the $15^{\text {th }}$ of February 2021, there were 2.28 persons/100 people vaccinated at the world level. See Figure 1. However, the rhythm of vaccination was highly different from one country to another as depicted in Figure 2, with Israel leading the way.

At the moment (February 2021), the probability of obtaining herd immunity is seen that will happen in the third quarter of 2021 (Charumilind et al., 2021). At the end of 2020 new versions of the Coronavirus (the British, the South African, the Brazilian) have been identified as the virus has mutated from its initial version, and these new versions are more infectious and have a higher transmission rate. It is considered that if these new strains of the virus become dominant, there will be a delay in obtaining herd immunity (Charumilind et al., 2021, p. 3) and stopping the pandemic.

\footnotetext{
${ }^{2}$ https://ec.europa.eu/info/live-work-travel-eu/coronavirus-response/safe-covid-19-vaccines-europeans_ro.
} 


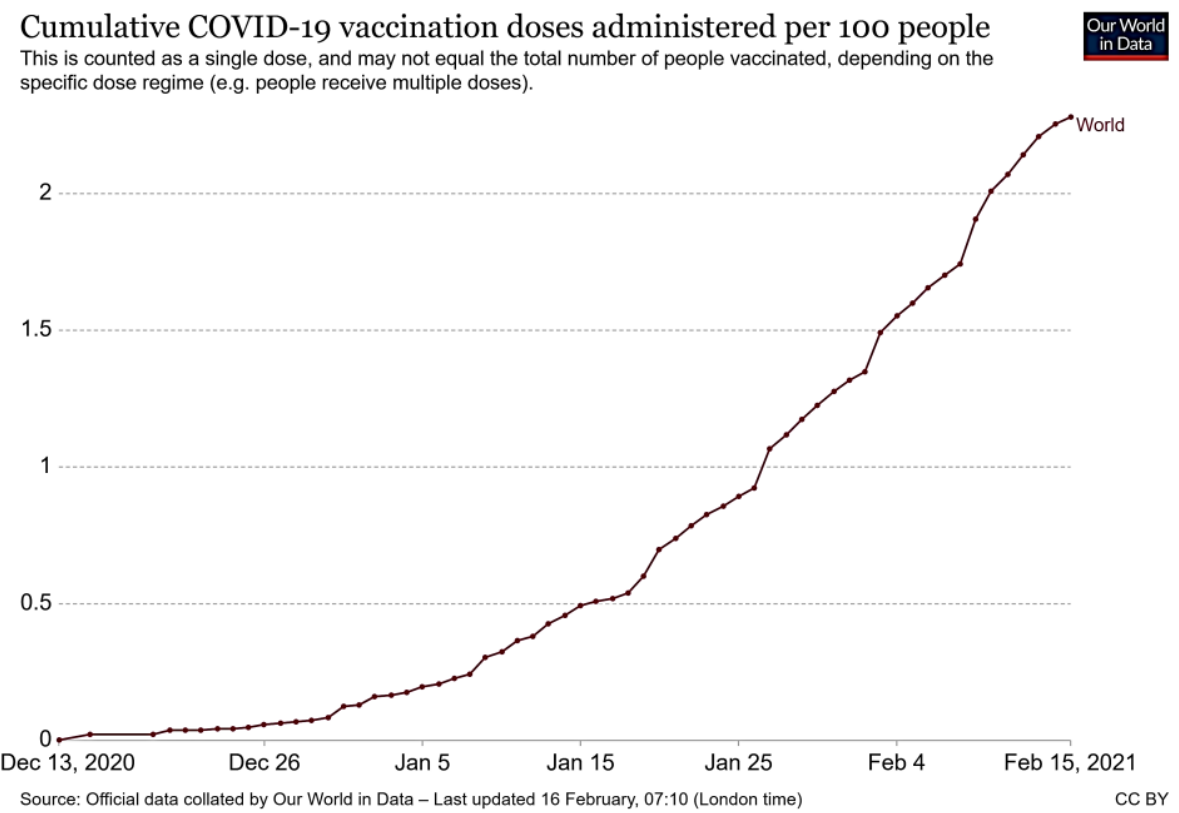

Figure 1. COVID-19 vaccines administered per 100 people at 15 February 2021 - world

Source: https://ourworldindata.org/covid-vaccinations.

COVID-19 vaccine doses administered per 100 people, Feb 15, 2021

Total number of vaccination doses administered per 100 people in the total population. This is counted as a single dose, and may not equal the total number of people vaccinated, depending on the specific dose regime (e.g. people receive multiple doses).

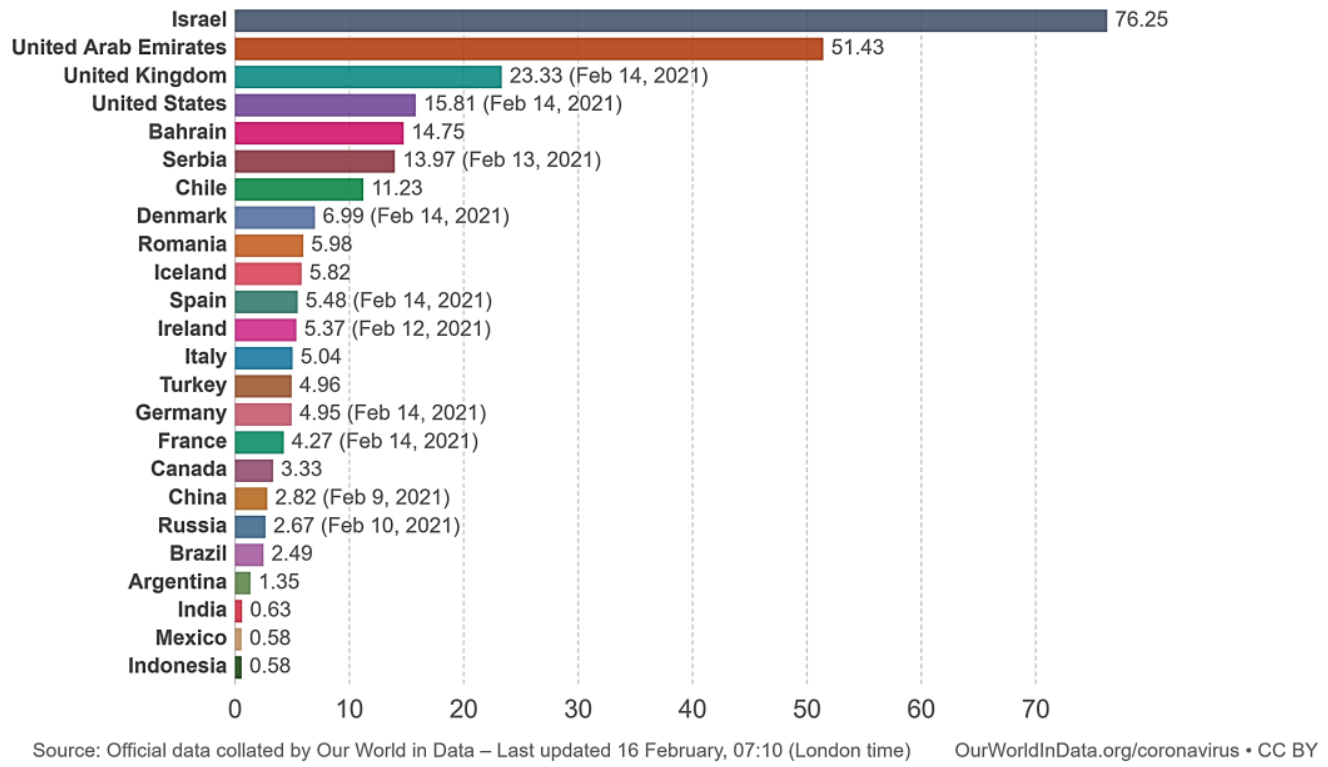

Figure 2. Cumulative COVID-19 vaccines administered per 100 people at 15 February 2021 countries

Source: https://ourworldindata.org/covid-vaccinations. 
The transition back to normality is considered that will happen when COVID-19 mortality will decrease and when the disease will not be a threat to society anymore (Charumilind et al., 2021). COVID-19 will continue to exist in the future, but as a normal disease (like flu) and even though health measures will still be needed in the future (such as testing and mask-wearing), society and social and economic life is expected to normalize. The normalization of society however depends on the impact that the COVID outbreak had and also on the future actions to be taken. This paper aims to analyze those two aspects as they are analyzed by specialists.

\section{Methodology}

The present paper has as main objective to identify the current opinions on the present COVID-19 crisis and its economic consequences, as well as the visions about future developments in the aftermath of the health and economic crisis.

The paper is based on a literature review methodology and the documentation research method. Scientific databases such as Emerald, Springer, Scopus, ScienceDirect, and Academy of Management were searched for papers using keywords such as COVID-19 and economic impact, COVID-19 and economic interdependencies, COVID-19 and supply chains, COVID-19 and the world after, COVID-19 and a number of industries recognized to be affected (such as tourism and travel, airlines and auto).

Also, documents and statistical data published on the official sites of different international organizations (World Health Organization, United Nations, World Trade Organization, OECD), and consulting companies were consulted (McKinsey Consultancy). Given that the events are ongoing, very recent papers and documents (2020-2021) were considered and analyzed. Table 2 presents a summary referring to the types of papers included in the present analysis.

Table 2. Papers and documents considered in the present analysis

\begin{tabular}{|l|c|}
\hline \multicolumn{1}{|c|}{ Types of papers } & Number \\
\hline COVID-19 and consequences (general) & 3 \\
\hline COVID-19 and economic impact & 5 \\
\hline COVID-19 and specific industries & 5 \\
\hline COVID-19 and the new economic order & 10 \\
\hline Documents from international organizations & 7 \\
\hline TOTAL & 30 \\
\hline
\end{tabular}

Content analysis was conducted and the main ideas were summarized in relation to the economic impacts of COVID-19 at multiple levels: global, macro-level, mezzo-level, micro-level: the global level included the world economy and the economic interdependencies at the international level; the macro-level referred to national economies; the mezzo-level envisaged the effects at the industry level and the micro-level referred to companies and the effect on companies. Another existing very important level, the individual level (personal) was not included in the analysis, as the purpose of the paper was rather to analyze systemic consequences of the health and economic crisis. 


\section{Opinions on COVID-2019 economic impacts at different levels}

COVID-19 had a huge effect on all aspects of economic of social life all over the world. It is considered that humanity was not prepared for the COVID-19 crisis (Brammer et al., 2020), as people, businesses, health systems, governments, and economies were all vulnerable and highly affected by the COVID-19 crisis.

This paper tries to discuss the main economic consequences of the global COVID-19 health crisis, that very quickly transformed into a global economic crisis. The profound economic crisis that was determined by the health crisis in 2020 is considered to be stronger than the financial crisis from 2007-2009 (Sharfuddin, 2020) and similar to the Great Depression from the 1930s (Kerr, 2020).

\section{The world economy and COVID-19 crisis}

It is known that in the last four decades, the intensity of the economic interdependencies between countries determined hyper-globalization as a rule for international relations (Kozul-Wright, 2020). Global value chains constituted the best representation of the globalization process in the last years.

The COVID-19 crisis determined the disruption of the global supply chains (Garofali, 2020), as the clearest expression of the globally integrated production processes and global systems of distribution (Gruszczynski, 2020). During the crisis, companies faced an increased risk of being dependent on foreign companies in their supplies and outsourcing became riskier than before (Zahra, 2021). The lack of diversification of sourcing strategies for many international companies, the geographical fragmentation, and the high dependence on dominant China as a global supplier led to high disruptions in global supply chains (Ibn-Mohammed et al., 2021).

International trade also declined due to economic lockdowns, disruption in international transportation, and protective measures adopted by countries (exports and imports restrictions) for products such as food, medical supplies, and hygiene products (Aramayo \& Vokoun, 2020), mainly due to the shortages of these goods. Data from the World Trade Organization (WTO) reveal that in the second quarter of 2020, the world merchandise trade volume decreased by $14,3 \%$ as compared to the first quarter of 2020, with North America and Europe, being the most affected regions, both in terms of exports and imports, as presented in Table 3. In terms of value, world merchandise trade was $21 \%$ lower (both in exports and in imports) in the second quarter of 2020 as compared to the second quarter of $2019^{3}$.

Table 3. Evolution of merchandise international trade volume 2020 compared to 2019 quarterly data $(\%)$

\begin{tabular}{|l|c|c|c|c|c|c|c|c|}
\hline \multirow{2}{*}{ Region } & \multicolumn{4}{c|}{ Exports (volume) } & \multicolumn{4}{c|}{ Imports (volume) } \\
\cline { 2 - 9 } & $\mathbf{2 0 1 9 Q 3}$ & $\mathbf{2 0 1 9 Q 4}$ & $\mathbf{2 0 2 0 Q 1}$ & $\mathbf{2 0 2 0 Q 2}$ & $\mathbf{2 0 1 9 Q 3}$ & $\mathbf{2 0 1 9 Q 4}$ & $\mathbf{2 0 2 0 Q 1}$ & $\mathbf{2 0 2 0 Q 2}$ \\
\hline World & 0,4 & $-0,8$ & $-2,8$ & $-15,0$ & 0,2 & $-1,4$ & $-2,5$ & $-13,6$ \\
\hline North America & 0,4 & $-0,4$ & $-1,5$ & $-24,5$ & 0,3 & $-2,4$ & $-2,2$ & $-14,5$ \\
\hline South and Central America & $-2,3$ & 0,7 & $-1,6$ & $-5,3$ & $-0,1$ & $-3,5$ & $-1,1$ & $-13,7$ \\
\hline Europe & 0,2 & 0,6 & $-4,3$ & $-21,8$ & $-0,3$ & $-1,7$ & $-2,9$ & $-19,3$ \\
\hline Asia & 1,4 & $-2,2$ & $-1,7$ & $-6,1$ & 0,2 & $-0,9$ & $-0,7$ & $-7,1$ \\
\hline Others & $-0,1$ & $-2,6$ & $-3,3$ & $-2,6$ & 1,7 & 0,4 & $-8,7$ & $-9,1$ \\
\hline
\end{tabular}

* Data is quarter over quarter (\% change in comparison with the previous quarter).

Source: World Trade Organization, https://www.wto.org/english/res_e/statis_e/daily_update_e/merch_latest.pdf.

\footnotetext{
${ }^{3}$ World Trade Organization, https://www.wto.org/english/res_e/statis_e/daily_update_e/merch_latest.pdf
} 
As we know, there is a mutual interdependence between international trade and the global demand and supply of goods and services. The contraction of international trade was determined by the shocks on the supply and demand in the world economy (UN, 2020). This was very visible in the service sector, where international tourism, international air traveling, and international merchandise transportation were victims of the health crisis (Gruszczynski, 2020).

\section{COVID-19 and macro-level consequences}

The economic impact on national economies is also profound. There is an agreement of the fact that the COVID crisis determined a global recession (Aramayo \& Vokoun, 2020, p. 64; Gruszczynski, 2020, p. 337; Leach et al., 2021). This manifests at the level of the global economy as discussed earlier, but also at the level of countries' economies.

Production declined in many countries, due to a decline in demand and purchasing power, as many people lost their jobs (Aramayo \& Vokoun, 2020, p. 64) and also due to more cautious spending of consumers due to future uncertainty. Accordingly, the economies of countries declined. Economies of the developed world declined in 2020 with around 4,9\%, determining a fall of the real global GDP of 3,5\%. Table 4 presents the evolution of the real GDP based on estimates for 2020, in selected regions and countries, and also the International Monetary Fund (IMF) projections of the real GDP for 2021 and 2022.

Table 4. Real GDP (annual \% change) - IMF projections

\begin{tabular}{|c|c|c|c|}
\hline Region & Estimate 2020 & Projection 2021 & Projection 2022 \\
\hline World & $-3,5 \%$ & $5,5 \%$ & $4,2 \%$ \\
\hline Advanced economies & $-4,9 \%$ & $4,3 \%$ & $3,1 \%$ \\
\hline United States & $-3,4 \%$ & $5,1 \%$ & $2,5 \%$ \\
\hline Euro Area & $-7,2 \%$ & $4,2 \%$ & $3,6 \%$ \\
\hline Japan & $-5,1 \%$ & $3,1 \%$ & $2,4 \%$ \\
\hline United Kingdom & $-10,0 \%$ & $4,5 \%$ & $5,0 \%$ \\
\hline Emerging markets and developing markets & $-2,4 \%$ & $6,3 \%$ & $5,0 \%$ \\
\hline China & $2,3 \%$ & $8,1 \%$ & $5,6 \%$ \\
\hline ASEAN - 5 & $-3,7 \%$ & $5,2 \%$ & $6,0 \%$ \\
\hline Russia & $-3,6 \%$ & $3,0 \%$ & $3,9 \%$ \\
\hline Brazil & $-4,5 \%$ & $3,6 \%$ & $2,6 \%$ \\
\hline
\end{tabular}

ASEAN - 5: Indonesia, Malaysia, the Philippines, Singapore, and Thailand.

Source: IMF (2021) https://www.imf.org/en/Publications/WEO/Issues/2021/01/26/2021-world-economic-outlookupdate.

It can be noticed that advanced economies are estimated to have had large decreases in their economies and real GDP in 2020, with Europe with the highest declines, being a region that was very hard hit by the COVID-19 outbreak. At the same time, China is the only country that is estimated to have had economic growth in 2020.

Unemployment raised in many countries during the COVID-19 crisis. Table 5 presents the unemployment situation in some of the OECD (Organisation for Economic Co-operation and Development) countries in 2020, as compared to 2019. It can be noticed that unemployment peaked in the second and the third quarters of 2020 in most countries and regions, with a slight recovery 
in the fourth quarter of 2020. According to International Labour Organization (ILO), the global unemployment rate was $6,5 \%$ in 2020 , with an increase of 33 million people in $2020^{4}$.

Table 5. Unemployment rates in $2020(\%)$

\begin{tabular}{|l|c|c|c|c|c|c|}
\hline $\begin{array}{c}\text { Regions and } \\
\text { Countries }\end{array}$ & $\mathbf{2 0 1 9}$ & $\mathbf{2 0 2 0}$ & $\mathbf{2 0 2 0 Q 1}$ & $\mathbf{2 0 2 0 Q 2}$ & $\mathbf{2 0 2 0 Q 3}$ & $\mathbf{2 0 2 0 Q 4}$ \\
\hline OECD Total & 5,4 & 7,1 & 5,4 & 8,6 & 7,6 & 6,9 \\
\hline $\begin{array}{l}\text { European } \\
\text { Union }\end{array}$ & 6,7 & 7,2 & 6,5 & 6,9 & 7,7 & 7,5 \\
\hline Euro Area & 7,6 & 8,0 & 7,3 & 7,6 & 8,6 & 8,3 \\
\hline Germany & 3,2 & 4,2 & 3,6 & 4,2 & 4,5 & 4,5 \\
\hline Turkey & 13,7 & - & 12,7 & 14,0 & 13,3 & - \\
\hline $\begin{array}{l}\text { United } \\
\text { Kingdom }\end{array}$ & 3,8 & - & 4,0 & 4,1 & 4,7 & - \\
\hline United States & 3,7 & 8,1 & 3,8 & 13,1 & 8,8 & 6,8 \\
\hline Romania** & 3,98 & 4,94 & 4,2 & 5,14 & 5,33 & 5,10 \\
\hline
\end{tabular}

* OECD had 37 member countries in total in February 2021.

** For Romania, data was retrieved from https://tradingeconomics.com/romania/unemployment-rate.

Sources: OECD (2021), https://www.oecd.org/sdd/labour-stats/unemployment-rates-oecd-update-february-2021.htm; https://tradingeconomics.com/romania/unemployment-rate.

\section{COVID-19 and industry levels effects}

As we have seen, the COVID-19 health crisis highly affected the economy with a large number of industries being negatively affected, while some other industries were positively influenced by the health crisis. At the same time, different activities and the way they are organized has changed in a number of sectors of activity and domains of the economy.

a. Industries negatively affected were either industries that collapsed during the Corona crisis or industries whose activities and revenues decreased to different extents in this period. Some examples are personal care services (such as cosmetics and hair salons), restaurants and bars industry, tourism, traveling, air transport and airlines, places of entertainment, such as theaters, concerts, cinemas, real estate industry (Ibn-Mohammed et al., 2021, p. 4; Zahra, 2021, p. 3).

The global airline industry has known an unpreceded decline during the COVID-19 outbreak. This was due to the decreased demand for flights and the huge decline in the international and local traffic, mainly due to measures taken by governments in response to the pandemic: border closure, travel restrictions, quarantine measures for international travelers (Amankwan-Amoah et al., in print), but also to the fear of traveling. This also resulted in job loss in the industry with around 400.000 employees being fired worldwide (Belhadi et al., 2021).

The auto industry is another industry negatively affected by the COVID-19 outbreak as only in Europe governments shut down factories and showrooms in the first lockdown of MarchApril 2020 (Belhadi et al., 2021). Due to decreased sales, automotive manufacturers also cut jobs. Such evolutions of this industry will highly affect the economies of countries (both emerging and developed) that rely on this industry.

The global tourism and hospitality industry, being vulnerable to threats such as pandemics, terrorist attacks, and natural disasters (Pillai et al., 2021), was highly affected by the COVID-19

\footnotetext{
${ }^{4}$ ILO (2021) https://www.ilo.org/wcmsp5/groups/public/@dgreports/@dcomm/documents/briefingnote/wcms_7670 28.pdf.
} 
outbreak. The hotel industry and the restaurant industry declined worldwide, as the number of tourists decreased in 2020 by $80 \%$ (Sharma et al., 2021).

b. Industries positively affected. Some industries were in high demand during the Corona crisis. The subsequent measures taken by authorities are the following:

- e-commerce developed in the context of increased home delivery processes determined first of the pandemic conditions and the lockdown decisions and further on the consumers' fear of shopping physically and the change in the consumer sentiment (Ibn-Mohammed et al., 2021,

PICBE | 881 p. 4). Due to the pandemics, the lockdowns, and the fear of the virus, online shopping increased even in countries that were more cautious with online shopping (like Germany, Romania, or Switzerland) (Sneader \& Singhal, 2021, p. 6).

- the information technology sector has known a large growth with many other activities being transferred online, with the move towards teleworking, telehealth, e-learning. And IT services, cybersecurity was in high demand (Zahra, 2021).

- the food industry has not been affected by the pandemic and the associated economic crisis as governments took care that food supply chains to function, so the agricultural products were relatively immune to the disruptions of the international trade and global supply chains (Kerr, 2020).

- medical equipment suppliers and sanitary products producers also have experienced growth in their sales (Zahra, 2021).

c. Numerous changes took place in the way certain activities take place, as well:

- global supply chains have been disrupted in many industries and for many enterprises, as international trade has been affected by lockdowns and measures of country closures taken by governments (Rebelo, 2020). This disruption of the supply and demand chains is seen as a globalized shock (Garofali, 2020, p. 57).

- education encountered in many countries a massive move towards distance learning, such as elearning via the internet or TV. Both teachers and pupils and students at all levels of education needed to readjust to a different way of interaction and learning.

- telemedicine and telehealth started to also increase for regular consultations with doctors and remote patient monitoring (Zahra, 2021).

- teleworking in general and remote working became the rule for all fields of activities where it was possible.

\section{Businesses and COVID-19}

Due to the COVID-19 crisis, many companies around the world (especially small and mediumsized companies) got bankrupt (Amankwan-Amoah et al., in print).

Many other businesses needed to change their ways of operations, based on new legislative norms, but also based on necessity:

- all of them had to consider new health and safety measures, that included distancing and sanitizing;

- some of them had to engage in remote working for all or a large part of their staff and this involved the use of digital technologies at work (Zahra, 2021);

- companies needed to become innovative in order to be able to survive in the hostile environment during the COVID-19 outbreak (Lee \& Trimi, 2021). 


\section{What comes after COVID-2019 health crisis}

There are many opinions that after the health crisis will be finished, the world is not going to go back to the way it lived in 2019 (Gruszczynski, 2020; Manyka, 2020; Sharfuddin, 2020) and that a new international order will arise. The world will be looked at as the pre-COVID-19 and the postCOVID-19 eras (Sneader \& Singhal, 2021, p. 2) and the new normal will mean a dramatic restructuring of both the social and the economic order (Sneader \& Singhal, 2021).

There are expected changes in the IDEOLOGY about the functioning of the actual world

PICBE |

882 or the world before COVID-19.

There are authors (Buscher et al., 2021) who consider that the COVID-19 crisis exposed the weak points of the neoliberal economic development model. They consider that the current economic ideology based on economic growth, capital accumulation, the dominance of market logic, and obtaining of profit at the center of the economic activity, has shown during the COVID-19 crisis that the system failed in health as well as in economic terms. Others see the present world economic system that is based on "the extreme use of resources and the search of infinite profit" as being based on an outdated logic (Garofali, 2020, pp. 58-59). Therefore, given the failures of the present economic system during the COVID-19 crisis and the fact that also history showed that economic growth does not necessarily translate into well being Buscher et al., (2021, p. 2), they propose a move away from the model of development that focuses on aggregate growth, towards a new economic framework that focuses on redistribution and care (the establishment of a universal basic income rooted in a universal social policy system) and that uses regenerative agriculture (based on biodiversity conservation). They militate for more sustainable and equal societies (Buscher et al., 2021).

Other authors, explain that due to the high general distrust in the "business as usual", a new form of stakeholder capitalism is seen to be necessary for the future (Sneader \& Singhal, 2021, p. 12). Stakeholder capitalism will have to better bridge businesses and communities, in which businesses will have to build trust for stakeholders (consumers, suppliers, workers, society, shareholders, etc.), to form social capital and to recognize that long term shareholder value creation should mean more than just centering on shareholders.

The new normality of economic interaction, based on a new culture and morality needs to be the basis of the new world economic order (Garofali, 2020). In this new normality, human environmentalism needs to prevail, and also the consolidation of new sustainable development objectives is needed.

The development models that have been dominant for a long time now, such as market liberalization, promotion of economic growth, globalization of carbon-intensive industries are seen to be highly challenged by the COVID-19 crisis (Leach et al., 2021) and it is considered that capitalism and development need re-thinking. Therefore, the post-pandemic transformations need to find post-capitalist alternatives of development that will be more resilient, that would ensure trust between authorities and citizens, and would bring inclusive and solidarity economies, in which the universality principle to be applied in all countries of the world. However, it is emphasized that in the end these required changes are a matter of political choice (Leach et al., 2021, pp. 9-10) and if politics at the world level will not be able to change direction, future shocks will hit even harder the humanity.

As part of the new international order, it has to be considered a balance between political totalitarianism (such as in China, Saudi Arabia, South Korea) and free-market economies (US, UK, EU), as both systems have shown different strengths in the fight with the pandemic (Sharfuddin, 2020, p. 255). 
New societal and business principles and competencies will be necessary to cope with the very fast-changing environment, such as resilience, agility, flexibility (Lee \& Trimi, 2021). The reconsideration of some of the main beliefs, among which the attitudes about efficiency versus resilience is necessary for the post-COVID-19 era (Manyika, 2020), where the capacity to recover fast from a difficult situation or period becomes more important than efficiency itself. Other principles to be followed after normalization from the COVID-19 crisis are reduced inequality between and within countries, the care economy, the sustainable real economy, shared prosperity, and global solidarity (Burrow, 2020, p. 28). Another principle that needs stronger emphasis in the after COVID world is international cooperation and coordination in all respects (UN, 2020).

There are also expected changes in the PRACTICAL ways of doing things. Different authors highlighted various directions that are seen that will be part of the new normal after the COVID-19 health crisis and we will present the main ones in the following.

At the global and geopolitical level, from the perspective of international cooperation:

- it is considered that in the long term, the world needs to develop a new multilateral system in which countries play a role in protecting global commons and on creating global public goods, also in which global regulations and global public institutions to guide policy initiatives at country international and country-level (Kozul-Wright, 2020, p.160). The multilateral institutions (such as United Nations, World Health Organization) need to be reviewed and to become more accountable to donors (Sharfuddin, 2020, p. 256).

- in the new order, new collaborative mechanisms are to be developed, so that globalization work for all (Sharfuddin, 2020). This is also emphasized by Manyika (2020, p. 27) who states that collective action is critical in order "to build economies that deliver inclusive economic growth, prosperity, and safety for all".

- a higher level of protectionism will emerge, as countries will try to protect some of their industries (Sharfuddin, 2020) and possibly higher tariffs will be applied in the future in certain industries (such as manufacturing).

- some consider that the global recession will determine a higher level of nationalism that will dominate the discussion on international cooperation (Sharfuddin, 2020, p. 248). And even though globalization cannot be ignored in the future, will take a step back (Sharfuddin, 2020, p. 248). In this context, deglobalization_is seen as a trend in which there will be a shift from global just-in-time supply chains towards localized business operations with local and regional supply chains (Bremmer, 2020, p. 29).

- global supply chains are expected to weaken and countries and companies will probably rely more on national and regional suppliers (Sharfuddin, 2020). The regionalization of supply chains will be one of the main structural changes that will take place at the international level (Manyika, 2020; Bremmer, 2020). Many consider that China and other Asian countries will lose their positions as main suppliers of cheap part components (Aramayo \& Vokoun, 2020), and other local and regional suppliers can emerge. Companies will focus on relocating activities outside China and will produce more locally or in the neighboring countries (Zahra, 2021). UN (2020), also emphasizes that in the future a sustainable trading system is needed and in this context, it is expected that local and regional trade and supply chains will grow.

- the focus on inward policies (re-localization and re-regionalization) will come as a disadvantage to countries that are labor-intensive and importing countries as part of the pre-Covid international standardization and global supply chains. As China and other Asian countries will be replaced as main suppliers of low-cost part components and products (Aramayo \& Vokoun, 2020), they will be economically affected more. 
At a more specific, industry-related level:

- health will become a stronger priority and more funding will be allocated to health, including for research for finding new vaccines and for the improvement of those that just recently have been developed, so that to cope with the new variants of the COVID-19 virus that appeared at the end of 2020. This will also involve cooperation and the sharing of information between countries (Sharfuddin, 2020). Also, innovation in medicine will be accelerated and a bio-pharma revolution with biology meeting technology might become prevalent in the future (Sneader \& Singhal, 2021, p. 8).

- e-commerce will face an even higher level of development, the activity will improve and higher competition between e-commerce players will take place (Sharfuddin, 2020).

- e-government services will be more developed in the future and citizens of countries will be able to pay their bills, taxes and communicate with local authorities easier through e-communication (Sharfuddin, 2020).

- tourism will be run based on new rules, with higher levels of health and safety controlled touristic location and with new rules of traveling internationally (COVID-passports and vaccination certificates). It is possible that local and national tourism to take precedence over international tourism. As far as international tourism is concerned, leisure travel is expected by some (Sneader \& Singhal, 2021) to become back to normal when people will become confident to travel again including international tourism and traveling. However, business travel (national and international) is not expected to get back to normal, like video calls, online meetings, and remote working will become the norm of business meetings in the future (Sneader \& Singhal, 2021) and this will affect negatively tourism and travel at international level.

At a more technological and procedural level:

- higher support for green and sustainable industries (Sharfuddin, 2020) will have a new emphasis in businesses, as a dominating issue in the years to come will be health. Therefore, green technologies will be the preference of the future. Similarly, at the local authorities level, more gardens and more open-air places will be part of future city planning. More countries will acknowledge the benefits of environmental sustainability and will invest more in green energy and green economy (electric cars, green infrastructure, and technology) and less carbon-based economies in order to diminish carbon emissions. We have the examples of the US, EU, China, Japan, Canada, South Korea, Colombia that all in one way or another engaged to reduce carbon emission and to invest in green growth (Sneader \& Singhal, 2021, p. 10).

- information technology and digital transformation will become even more immersed in all types of activities, with many of the online activities during the lock-down periods, rather moving towards this form even after the health crisis will be over. For example, communication via internet technology will become prevalent at all levels, including official communication between countries, as intergovernmental meetings will probably be virtual (Sharfuddin, 2020). Also, many international companies will prefer to use digital technologies, as they are cheaper, they provide better access and they ensure higher productivity (Zahra, 2021, p. 4). Greater acceleration of digitization, using IT, and the new forms of working are expected to occur (Sneader \& Singhal, 2021) and the COVID-19 crisis is seen as speeding up these processes. The advanced digital technologies (such as artificial intelligence, machine learning, 3-D printers, virtual reality, and Internet of Things (IoT) will contribute to dealing with health issues, social issues, and economic issues in the future (Lee \& Trimi, 2021, p. 14). The today Fourth Industrial Revolution or digital transformation will be accelerated in the future, and cyber connectivity and automatic control of 
manufacturing processes will be the norm in the future in developed countries (Lee \& Trimi, 2021, p. 15).

- due to information technology, remote working will remain as one main way to work in the future. A lot of the high skilled jobs (such as that of IT specialists, finance, insurance, and others) will be conducted away from the office in the future (Sneader \& Singhal, 2021).

- there are opinions (Zahra, 2021, p. 4) that innovation will take place on a global scale, as entrepreneurs all over the world, including those with international activities, will try to find solutions to the problems determined by the COVID-19 crisis and its consequences and will become more innovative.

Some specialists consider that in order to ensure collective survival, future investments should be in health, global economy, and multilateralism (Burrow, 2020, p. 28).

\section{Conclusion}

The COVID health crisis had a tremendous impact on social and economic life all over the world, throwing humanity in a global economic recession. Specialists and statistical data showed that economic impacts have been felt at the world level (disruptions of global supply chains and international trade), at a macro-economic level as country economies were affected (decline of production, demand and of real GDP and increase in unemployment), at mezzo-level as different industries were affected (tourism, airlines, auto in a negative manner, while e-commerce, information technology, medical equipment in a positive manner), at micro-level (as many small and medium-sized companies went bankrupt, some diminished their activities and other companies needed to change their way of doing business by shifting to remote working).

A question that is of concern for many specialists is: How will the world evolve after the COVID crisis will be over? And the specialists' points of view and theories are that there is the need for changes in the economic ideology, with the rise of a new economic framework that will offer a post-capitalist alternative to economic development, that will be based on sustainable and equal societies, resilient economies, shared prosperity, global solidarity, international cooperation.

This paper contributed with a synthesis of opinions of specialists about two major aspects: a) about the economic impacts of the COVID crisis at different levels and b) about the future of the world and the economic order after the COVID crisis, using very recent literature and documents published in 2020-2021.

\section{References}

Aramayo, L. G. D. \& Vokoun M. (2020). Covid-19 and international trade. In Gardini, G. L. (Ed). The world before and after Covid-19, European Institute of International Studies (EIIS), Stockholm, 57-61.

Amankwah-Amoah, J., Khan, Z. \& Osabutey, E. L. C. (in print). COVID-19 and business renewal: Lessons and insights from the global airline industry, International Business Review, in print.

Belhadi, A., Kamble, S., Jabbour, C.J.C., Gunasekaran, A., Ndubisi, N.O. \& Venkatesh, M. (2021). Manufacturing and service supply chain resilience to the COVID-19 outbreak: Lessons learned from the automobile and airline industries, Technological Forecasting and Social Change, 163 , in print.

Brammer, S., Branicki, L., \& Linnenluecke, M.K. (2020). COVID-19, Societalization and Future of the Business in Society, Academy of Management Perspectives, 34(4), 493-507. 
Bremmer, I. (2020). How will the world be different after COVID-19?, Finance \& Development, June 2020. Retrieved from https://www.imf.org/external/pubs/ft/fandd/2020/06/how-willthe-world-be-different-after-COVID-19.htm.

Burrow, S. (2020). How will the world be different after COVID-19?, Finance \& Development, June 2020. Retrieved from https://www.imf.org/external/pubs/ft/fandd/2020/06/how-willthe-world-be-different-after-COVID-19.htm.

Buscher, B., Feola, G., Fischer, A., Flechter, R., Gerber, J.F., Hartcourt, W., Koster, M., Schneider, M., Scholtens, J., Spierenburg, M., Walstra, V.\& Wiskerke, H. (2021). Planning for a world beyond COVID-19: Five pillars for post neoliberal development. World Development, 140, in print.

Charumilind, S., Craven, M., Lamb, J., Sabow, A. \& Wilson, M. (2021). When will the COVID-19 pandemic end? An update. McKinsey\& Company. Retrieved from https://www.mckinsey .com/industries/healthcare-systems-and-services/our-insights/when-will-the-covid-19pandemic-end.

Ibn-Mohammed, T., Mustapha, K.B., Godsell, J., Adamu, Z., Babatunde, K.A., Akintade, D.D., Acquaye, A., Fujii, H., Ndiaye, M.M., Yamoah, F.A. \& Koh, S.C.I. (2021). A critical analysis of the impacts of COVID-19 on the global economy and the ecosystems and opportunities for circular economy strategies, Resources, Conservation \& Recycling, 164, in print.

International Labour Organization (ILO) (2021). ILO Monitor: COVID-19 and the world of work. Seventh edition. Updated estimates and analysis, 25 January 2021, Retrieved from https://www.ilo.org/wcmsp5/groups/public/@dgreports/@dcomm/documents/briefingnote /wcms_767028.pdf.

International Monetary Fund (IMF) (2021). World Economic Outlook. Latest Update January 2021. Retrieved from https://www.imf.org/en/Publications/WEO/Issues/2021/01/26/2021 world-economic-outlook update.

Garofali, A. (2020). International economic outlook in times of Covid-19 - A SWOT analysis-. In Gardini, G. L. (Ed). The world before and after Covid-19, European Institute of International Studies (EIIS), Stockholm, 57-61.

Gruszczynski, L. (2020). The COVID-19 Pandemic and International Trade: Temporary Turbulence or Paradigm Shift?, European Journal of Risk Regulation, 11, 337-342.

Kerr, W. A. (2020). The COVID-19 pandemic and agriculture: Short and long-run implications for international trade relations, Canadian Journal of Agricultural Economics, 68, 225-229.

Kozul-Wrights, E. (2020). Recovering Better from COVID-19 Will Need a rethink of Multilateralism, Development, 63, 157-161.

Leach, M., MacGregor, H., Scoones I. \& Wilkinson, A. (2021). Post-pandemic transformations: How and why COVID-19 requires us to rethink development, World Development, 138, in print.

Lee, S.M. \& Trimi, S. (2021). Convergence innovation in the digital age and in the COVID-19 pandemic crisis, Journal of Business Research, 123, 14-22.

Manyika, J. (2020). How will the world be different after COVID-19?, Finance \& Development, June 2020, Retrieved from https://www.imf.org/external/pubs/ft/fandd/2020/06/how-willthe-world-be-different-after-COVID-19.htm.

OECD (2020). Unemployment Rates New Release 10 February 2021. Retrieved from https://www.oecd.org/sdd/labour-stats/unemployment-rates-oecd-update-february2021.htm. 
Pillai, S. G., Haldorai, K., Seok Seo, W. \& Kim, W.G. (2021). COVID-19 and hospitality 5.0: Redefining hospitality operations, International Journal of Hospitality Management, 94, in print.

Rebelo, S. (2020). How will the world be different after COVID-19?, Finance \& Development, June 2020. Retrieved from https://www.imf.org/external/pubs/ft/fandd/2020/06/how-willthe-world-be-different-after-COVID-19.htm.

Sharfuddin, S. (2020). The world after Covid-19. The Round Table, The Commonwealth Journal of International Affairs, 109(3), 247-257.

Sharma, D. G., Thomas, A. \& Paul J. (2021), Reviving tourism industry post-COVID-19: A resilience-based framework, Tourism Management Perspectives, 37, in print.

Sneader, K. \& Singhal, S. (2021). The next normal arrives: Trends that will define 2021- and beyond. McKinsey \& Company, Retrieved from https://www.mckinsey.com/featuredinsights/leadership/the-next-normal-arrives-trends-that-will-define-2021-and-beyond.

United Nations (2020). COVID-19: Implications for Trade and Environment, Retrieved from https://wedocs.unep.org/bitstream/handle/20.500.11822/32205/Covid.pdf?sequence=1\&is Allowed=y.

World Health Organization (2020). Naming the coronavirus disease (COVID-19) and the virus that caused it, Retrieved from https://www.who.int/emergencies/diseases/novel-coronavirus2019/technical-guidance/naming-the-coronavirus-disease-(covid-2019)-and-the-virus-that -causes-it.

World Health Organization timeline (2021), Retrieved from https://www.who.int/emergencies/ diseases/novel-coronavirus-2019/interactive-timeline?gclid=Cj0KCQiA1 KiBBhCcARIs APWqoSonrfwKiCfZ9hsfzin_uqvUZvKsCa13jqJC3imCXFEXHzZptDDpYGcaAhDKE ALw_wcB\#!.

World Trade Organization (2020). Second Quarter 2020 Merchandise Trade, Retrieved from https://www.wto.org/english/res_e/statis_e/daily_update_e/merch_latest.pdf.

Zahra, S.A. (2021). International entrepreneurship in the post Covid world, Journal of World Business, 56, in print.

https://www.worldometers.info/coronavirus/.

https://ourworldindata.org/covid-vaccinations.

https://ec.europa.eu/info/live-work-travel-eu/coronavirus-response/safe-covid-19-vaccineseuropeans_ro.

https://tradingeconomics.com/romania/unemployment-rate. 